https://doi.org/10.48009/2_iis_2010_54-65

\title{
USING TECHNOLOGY TO TEACH CRITICAL THINKING IN HIGHER EDUCATION - A LOOK AT AN UNDERGRADUATE BUSINESS COURSE
}

\author{
Mak Khojasteh, Winston-Salem State University, khojastehm@wssu.edu \\ Janice Witt Smith, Winston-Salem State University, jwsmithphd@nc.rr.com
}

\begin{abstract}
According to studies conducted by business organizations and employer associations as it relates to U.S. college graduates (SHRM 2007), college graduates are ill prepared for the business environment, in part due to their lack of expertise with technology. Indeed, the popular press indicates that our students fall behind in STEM areas - science, technology/ engineering, and mathematics (STEM). Rather than the United States leading the world in innovation in these fields, we are falling far behind as a country and losing our competitive advantage. Among the solutions offered to combat this erosion in competitive position and respect within the world economic community is integration of both critical thinking skill building and technology into the core curricula. This reported study describes an attempt to utilize existing technology at a small, Master's I level university to engage students in critical thinking skill building during an on-line business course with a Blackboard ${ }^{\circledR}$ instructional platform. Less than 50\% of the students in a distance-learning $H R$ business course actively and consistently embraced and engaged in using the required technology.
\end{abstract}

Key Words: Critical thinking, Case Study, Blackboard, Technology Acceptance Model, Readiness to Learn, STEM, competitive advantage

\section{INTRODUCTION}

According to studies conducted by business organizations and employer associations as it relates to U.S. college graduates [33], college graduates are ill prepared for the business environment, in part due to their lack of expertise with technology. Indeed, the popular press indicates that our students fall behind in STEM areas - science, technology/engineering, and mathematics (STEM). Rather than the United
States leading the world in innovation in these fields, we are falling far behind as a country and losing our competitive advantage. Among the solutions offered to combat this erosion in competitive position and respect within the world economic community is integration of both critical thinking skill building and technology into the core curricula. This reported study describes an attempt to utilize existing technology at a small, Master's I level university to engage students in critical thinking skill building during an on-line business course with a Blackboard ${ }^{\circledR}$ instructional platform.

Research within information technology field also indicates that the use of technology in business is ubiquitous. That is, the use of e-mail, personal financial application, web browser, and some type of access to social networks is the norm, rather than the exception in business. The integration of technology in business organizations requires that individuals matriculating at institutions of higher learning have a knowledge of and healthy respect for information technology in its various platforms. Furthermore it is critical that the end user (in this case, the student) embraces the technology, accepts it, and develops expertise in using it. Within corporate America, as is in academe, there is not a wholesale acceptance of technology and the benefits it may bring to both the business and the end user. Indeed, technology systems fail within these environments for a myriad of reasons $[8,22]$. In addition, there are a number of systems that are abandoned in the midst of their design or construction [24], and institutions of higher learning, like corporate entities, find that some of the technology systems do not fulfill the user expectations when implemented. Davis's [6] revision of the Technology Acceptance Model (TAM) found that technology implementation fails because the end user does not perceive that the system is useful and there is a lack of ease in using the system. 
The reported study looks at the use of Blackboard discussion board and water cooler in facilitating the development of critical thinking skills within an on-line advanced-junior level course in Human Resource Management. We begin by defining critical thinking, and the importance of developing critical thinking skills. We then describe the use of technology and user response to technology within this course. What is critical to note is that, similar to what other research has consistently shown, is that there were areas of definite failure in the integration of Blackboard in this course, not merely due to technological issues but those that are related to organizational and psychological issues - the people side of the equation, if you will $[1,7$, 21].

A number of reports have been published on workforce readiness and whether or not new entrants to the U.S. workforce have the requisite skills, training and knowledge to assist in global competition. The consensus has been that, compared to most other industrialized countries, the U.S. educational system has significant deficiencies in preparing skilled workers to enter the workforce. As a result, the lack of skilled workers in a global competitive market will continue to negatively impact U.S. businesses overall, increase the incidence of off-shoring, and further exacerbate the unfavorable balance of trade that the U.S. as a whole is experiences. In a 2006 report by Partnership for $21^{\text {st }}$ Century Skills and Society for Human Resource Management [25], the following performance dimensions/skill areas were identified as needed for $21^{\text {st }}$ Century Workplace Entrants:

- Written communications

- Professionalism/Work Ethic

- Critical Thinking/Problem Solving

- Oral Communications

- Ethics/Social Responsibility

- Reading Comprehension

- Teamwork/Collaboration

- Diversity

- Information Technology/Application

- English Language

A scorecard was created which evaluated the skill levels of high school graduates, two-year college/technical school graduates, and four-year college graduates. High school graduates were not identified as having skills at the excellent level; only $25.7 \%$ of the employers identified two-year college/technical school graduates as excellent with information technology application. Four-year college graduates were considered excellent by $20 \%$ or more of the respondents on everything except written communications $\quad(27.8 \%$ identified as deficiency), writing in English, and Leadership, where $27.8 \%, 26.2 \%$, and $23.8 \%$ identified these as deficiencies. In addition, approximately $69.6 \%$ of the employers participating in the symposium indicated that high school graduates were deficient in critical thinking/problem solving skills; $22.8 \%$ of two-year college/technical school graduates were also deficient in this area. Only $27.6 \%$ of the college graduates were deemed "excellent" in critical thinking/problem solving skills.

Furthermore, a 2007 Symposium on the Workforce Readiness of the Future U.S. Labor Pool, conducted by the Society for Human Resource Management, the Conference Board, Corporate Voices for Working Families, and Partnership for $21^{\text {st }}$ Skills [33] was held in which further discussion centered on the survey results. In this report, symposium participants agreed that while the global competitive environment was more important today than ever before, the systems and infrastructure needed in the U.S. to compete in the global economy were sorely lacking. There is currently an acute shortage of skilled labor, and even the optimistic predictions are that these shortages will worsen.

This study also suggested that the educational system needs to improve its teaching of applied skills such as critical thinking and problem solving, which need to be taught in academic, content-rich courses. A criticism has been made in the recent media that much of college-centered teaching has been focused on rote memorization with little or no practical application. In many educational settings, with the large class sizes and lack of adequate faculty support within and outside the classroom, multiple choice/guesses tests are the norm rather than the exception. These types of tests usually do not require critical or evaluative thinking, but rather knowledge and comprehension (according to Bloom's 1956 Taxonomy)[4].

With this and other practitioner research clear and unambiguous that there needs to be a paradigm shift in the way that students are educated, particularly in the realm of critical 
thinking and problem solving skills, this research study examines a model for critical thinking.

In Bloom's taxonomy[4], cognitive objectives are identified which deal with a student's ability to perform in educationally desirable ways after they have received instruction. Guillemette [18] identified these cognitive objectives in six major subcategories, in which the following items are listed in order of complexity:

(a) Knowledge - One's ability to recall the information;

(b) Comprehension - The lowest level of understanding in which students both understand what is being presented and are able to use this in their immediate context;

(c) Application - Using a real context in which the information is used in a way that may be different than the way presented. It consists of using the information, principles, generalized methods and theories in particular concrete situations;

(d) Analysis - Breaking down a communication into its subcomponents based on some schema ... . .

(e) Synthesis - Developing innovative pattern of structure from the elements presented

(f) Evaluation - Making quantitative or qualitative evaluative judgments about the ideas, methods, and solutions.

Many undergraduate classes incorporate the first three subcategories in their learning environment. However, there may be a deficit in the utilization of analysis, synthesis and evaluation. This paper examines an approach in a distance-learning undergraduate human resource management class in training, development and performance management in which higher order skills are being developed and honed. To make the argument for the inclusion of critical thinking as part of the content of collegiate courses, the following format is used:
I- $\quad$ Definition of Critical Thinking
II- Importance of Critical Thinking in Higher Education
III- Characteristics of Critical Thinking
IV- Disposition in Critical Thinking
V- $\quad$ How to Teach Critical Thinking

VI- Integration of Critical Thinking and
Technology in HR Class

LITERATURE REVIEW

There are numerous definitions of Critical Thinking (herein referred to as CT) in current literature. Facione [9] was among the first to establish a consensus definition of critical thinking within the field of philosophy. $\mathrm{He}$ utilized a Delphi technique to identify and describe the skills and dispositions that characterize critical thinking. Forty-six experts in this study went through a six-round process and achieved both a consensus definition of critical thinking and its core cognitive skills and affective dispositions. In addition, they developed descriptions of critical thinking, such as "habitually inquisitive, flexible, orderly in complex matters, and diligent in seeking relevant information." Facione [10] identified interpretation, analysis, evaluation, inference, explanation and self-regulation as the cognitive skills at the core of critical thinking. In addition, others have expanded the definition of critical thinking to include several other factors. First, they include the individual's disposition toward critical thinking; and, secondly, they differentiate between their cognitive skills and their approach to life in general [10].

There are two categories of CT. The first, which is approached in higher education has a strong focus on formal knowledge within the boundaries of a discipline, to abstract logical argument in a search of greater truth. This is known as "logicism," which implies that good thinking is logical thinking. In the logicism approach [38], Critical Thinking can be defined as "utilization of cognitive skills to increase the probability of a desirable outcome" [20:70). Logical CT is a goal-directed, reasoned thinking that strives to solve problems, formulating inferences and making decisions when the thinker is applying skills that are effective for a particular context [19:3].

The other category of CT has a broader, more comprehensive approach which goes beyond the constraints of "logicism" to incorporate a holistic approach such as imagination (15:3). Barbara Fowler, Longview Community College, conducted an examination of a number of definitions of critical thinking in her article entitled, "Critical Thinking Across the Curriculum Project," 
http://mcckc.edu/longview/ctac/definitions.htm $2 / 2 / 28$. She offered the several additional definitions of critical thinking, which include the following: "Critical thinking is deciding rationally what to or what not to believe"[14:40]. "Critical thinking is the use of those cognitive skills or strategies that increase the possibility of a desirable outcome. It is used to describe thinking that is purposeful, reasoned and goal directed - the kind of thinking involved in solving problems, formulating inferences, calculating likelihoods, and making decisions

when the thinker is using skills that are thoughtful and effective for the particular context and type of thinking task. Critical thinking also involves evaluating the thinking process

- the reasoning that went into the conclusion we've arrived at the kind of factors considered in making a decision. Critical thinking is sometimes called directed thinking because it focuses on a desired outcome." [19].

In their paper "Defining Critical Thinking" for the National Council for Excellence in Critical Thinking Instruction, Scriven and Paul [29] defined critical thinking as "the intellectually disciplined process of actively and skillfully conceptualizing, applying, analyzing, synthesizing, and or evaluating information gathered from, or generated by, observation, experience, reflection, reasoning or communication, as a guide to belief and action." Critical thinking skills are necessary in enabling students "to deal effectively with social, scientific, and practical problems" [31:42]. That is, a person's ability to think critically is a key factor in their ability to effectively solve problems. Tempelaar [35] found that many teachers struggle with engaging students in critical thinking activities. Other researchers found that students seldom use critical thinking skills in their evaluation and solving of real world, complex problems [3, 28].

\section{IMPORTANCE OF CRITICAL THINKING IN HIGHER EDUCATION}

The drastic and unprecedented change in technology and workplace created a need for critical thinking more than ever before [20:69). Therefore "the development of critical thinking is often put forward as an ideal of higher education" [37: 1]. The Carnegie Council on Adolescent Development in 1989 concluded there is no reason that young adolescents cannot engage in critical and higher order thinking. The United States Congress through the Goals 2000: Educate America Act of 1990, established five national educational goals. One of these goals called for increase in number of college graduates who can think critically and be effective in problem solving. Others discussed the importance of preparing college students who are able to synthesize and think effectively. Factors such as technology, workforce, and global competition require critical thinking to be incorporated in the education system. As the SHRM Workplace Readiness Report [33] and Symposium information related earlier in this document indicate, some progress has been made; however, it is not sufficient for the U.S. workforce to complete effectively in the global economic environment.

In addition, the critical thinking movement is not limited to the United States. Other countries such as Canada also placed an emphasis on education models that produce students who are able to think critically [39:29]. Critical thinking is essential as a tool of inquiry.

\section{CHARACTERISTICS OF CRITICAL THINKERS}

- Ferrett [13] suggests that the attributes of a critical thinker include the following:

- Asks questions that are pertinent and germane to the topic at hand

- Evaluates statements and arguments made by self and others

- Admits a lack of understanding or information when applicable

- Is curious about the world and the material/problem

- Has interest in finding new solutions

- Can clearly define appropriate set of criteria for analyzing ideas

- Is willing to examine opinions, assumptions and beliefs and evaluate them against facts

- Listens carefully and actively to others and is able to provide feedback

- Sees critical thinking as a lifelong process in which one continues to self assess 
- Suspends judgment until all relevant facts and information have been gathered and considered

- Seeks evidence to support assumption and beliefs

- Is able to update or modify opinions when new facts are found

- Looks for evidence or proof to substantiate thinking

- Examines problems closely

- Is able to reject incorrect or irrelevant information

Scriven and Paul [30] add the following attributes to describe a well-cultivated critical thinker:

- Raises vital questions and problems, formulating them clearly and precisely

- Gathers and assesses relevant information, using abstract ideas to interpret it effectively comes to wellreasoned conclusions and solutions, testing them against relevant criteria and standards

- Thinks open mindedly within alternative systems of thought, recognizing and assessing, as need be, their assumptions, implications and practical consequences; and

- Communicates effectively with others in figuring out solutions to complex problems.

The extant literature reveals additional characteristics of CT, which include the following: [2, 3]: Motivation to think critically; desire for discovery; curious mindset; knowledge of subject; valuing change; tolerance for ambiguity; flexible mental commitment; controlled skepticism; willingness to suspend judgments; and inquisitiveness.

Facione [11] provides the following consensus statement of the ideal thinker:

"The ideal critical thinker is habitually inquisitive, well-informed, trustful of reason, open-minded, flexible, fair-minded in evaluation, honest in facing personal biases, prudent in making judgments, willing to reconsider, clear about issues, orderly in complex matters, diligent in seeking relevant information, reasonable in the selection of criteria, focused on inquiry, and persistent in seeking results which are as precise as the subject and the circumstances of inquiry permit. Thus, educating good critical

thinkers means working toward this ideal. It combines developing CT skills with

nurturing those dispositions which consistently yield useful insights and which are the

basis of a rational and democratic society."

Students in higher education should have an opportunity to both think freely and to be able to effectively challenge other students' ideas with their own. Critical thinking is both the ability to think critically and to argue logically, an ability that employers in the global marketplace greatly value. Yang [40] summarizes arguments that one of the hallmarks of education is to teach and develop the critical thinking skills of both undergraduate and graduate students $[2,11,39$, 40].

\section{HOW TO TEACH CRITICAL THINKING}

Critical thinking requires development and application of rigorous standards of excellence, as well as effective communication and problemsolving abilities. Furthermore, a well-cultivated critical thinker will also commit to overcome our stereotypes, egocentrism, sociocentrism, and mental models that no longer work. Using the educational literature to inform, a review of Bloom's [4] taxonomy is appropriate. In this categorization scheme, Bloom and the committee of colleges that were part of the study identified that there are three domains in which educational activities can occur:

- Cognitive domain, which includes mental skills or knowledge

- Affective - growth in feelings or emotional areas - attitude

- Psychomotor - manual or physical skills (skills)

The cognitive domain is the category in which workforce readiness activities would usually occur. Within what is now known as "Bloom's Taxonomy," the cognitive domain involves knowledge and development of intellectual skills. This involves the recall or recognition of specific facts, procedural patterns, and concepts that serve in the development of intellectual skills and abilities. Within this domain, there are six specific categories, listed below from the simplest to the most complex:

Many colleges and universities are offering courses designed to enable student to think in a 
critical manner as a part of the general education requirements. Critical Teaching cannot take place unless both teacher and students can think critically. A person with disposition for critical thinking can relate to the concept and is able to articulate the meaning and application of critical thinking. A teacher who intends to teach the subject and a student who intends to become a critical thinker must possess the following predispositions: Perkins et al. [27] present Triadic Dispositional Theory-TDT, indicating that all intellectual behavior requires three distinct and separable components. The three components are ability, sensitivity, and inclination.

Ability refers to know-how, capability and skill required to get engaged in a specific behavior. For example, a person with ability to suspend judgment can refrain her/himself from making a hasty and premature judgment.

Sensitivity. according to Perkins et al [27:132] refers to the degree of alertness for appropriate opportunities to model a specific behavior For example, a person sensitive to suspend judgment is aware that quick and immature judgment may take place and is willing to abstain from premature judgment.

Inclination is a tendency to behave in a specific manner for example, a person with inclination to suspend judgment, can naturally refrain from making an immature judgment.

All three factors of ability, sensitivity, and inclination form a triad of necessary and sufficient conditions [23:31]. It is important to realize that all of are interrelated and contributing factors to critical thinking. It means all three factors must be present and absence of one would prevent the required conditions to critical thinking. However, one must understand that high marks in all three factors does not guarantee or even predict a higher propensity to critical thinking. The overall high mark simply means that an individual is more or less inclined to use the skill she/he possesses to think critically [12:38].

Teaching critical thinking is as complicated as thinking critically. There are several prerequisites for teaching critical thinking.

- Student's Aptitude, which includes motivation to learn; acceptance of controversies; desire for discovery through sprit of openness to learn; truthseeking mentality; self-directed learning is associated with CT; attitude and willingness [2, 3]

- $\quad$ Professor Aptitude, which includes

Although review of literature reveals the lack existence of sufficient information regarding dispositional elements of college educators [2:31], nevertheless, students and professors share some these aptitudes.

- In-depth-knowledge of the subject

- Truth-seeking mindset [2:36-37].

- Inclination to use CT [2:31].

- Acceptance of controversies

In higher education, the model could move from faculty-centered "control" of learning (typically in a basic, introductory undergraduate course) to student-centered "control" of learning, consistent with adult learning theory. In general, all adults like to be active participants in their own learning.

\section{UNDERGRADUATE COURSE IN TRAINING AND DEVELOPMENT}

Sample 1: Undergraduate HR Distance Learning Course in Training, Development and Performance Management (all eleven distance learning students were on-campus students who were either traditional undergraduates (8 of 11) or nontraditional students who were working as staff on campus. Students in this course were required to maintain electronic journal entries to capture their thinking and growth in knowledge, wisdom and understanding as it related to course material. They were required to apply this understanding to training they developed on cultural diversity, leadership, and performance management. These training packages included multimedia presentations, pre- and post-tests, electronic icebreakers, instructor manuals, and test questions. Their training audience were HR professionals who had not been exposed to those particular concepts in the past but would have to transfer their knowledge into their current environments.

Using Chickering and Gamson's 2008 study [5] on effective practices for undergraduate learning, the following steps were taken to ensure that students had contact prior to the course. First, an e-mail was sent by the faculty member to students enrolled in the course. This e-mail was 
sent through the campus e-mail system, using the official university e-mail address. This e-mail also included the faculty member's expectations and learning objectives for the course; provided a description of the extent to which instructional delivery would be through technology; and providing personal information about the faculty member to create an inviting climate for the student. Secondly, a clear expectation was set that the students would be placed into small learning groups to have on-line discussions, as well as would participate in larger group discussions utilizing Blackboard's asynchronous discussion board. Each student was required to access discussion board at least 4 times per week and to provide substantive answers to the questions or comments of other students. There was also a requirement for each student to create his/her own webpage. However, because the students were personally familiar with each other, we modified the original model to exclude their creating a webpage, but strongly encouraging them to engage in Water cooler discussions to enable them to build community.

Within Blackboard, we also created a section called "Water Cooler," which allowed for personal statements and informal selfdisclosures, both of which would make the course more user friendly. Students would not be responding to an anonymous "keystroke" but would be responding to real people whose faces and background would be familiar to them.

In addition, we utilized action-learning techniques such as case studies, discussion board, on-line assessments, project/workshop, and on-line blogging to facilitate responses to the $5 \mathrm{Ws}$ and $\mathrm{H}$ open-ended questions (who, what, when, where, why and how questions). The final technological piece was the use of a conference call utilizing ConferenceCall pro free conferencing tool. This conference call was utilized to share information, to discuss the syllabus, and to determine what, if any, questions the students had about the course, technology, expectations, and the like. Only 4 of the 11 students joined in on the call. Three of the four who participated performed extremely well in the course. The fourth was distracted on the call by her toddler child and never significantly engaged in the call or follow-up activities. This format of involving the end user in the purpose, use, opportunities and challenges of integrating technology was consistent with organizational research regarding technology usage and involving the end user in planning, types of technology, and integration of technology into their daily work world [6].

Less than $60 \%$ of the students heavily engaged in Blackboard; $25 \%$ of the students failed to actively engage; and the "new" students failed to utilize Blackboard discussion board as a method for building community. In short, while the use of Blackboard and the requirement for frequent engagement within Blackboard was widely communicated, there was limited consistent response to this requirement. Despite the frequent reminders for students to engage in Blackboard's discussion board for feedback and building community several students who did not do so, made a conscious decision to forgo those points.

\section{CRITICAL THINKING COMPONENTS OF UNDERGRADUATE CLASS}

There were four specific activities that formulated the critical thinking approach in this course. Supplemental reading materials were placed in Course Documents, and students were required to read, answer questions, and "compare and contrast" or "critically analyze or evaluate" the material, integrating it with text material. Use of course documents as a repository eliminated student excuses of lack of accessibility to materials or inability to pay to print the materials. They were able to read the materials on line.

Open-ended questions were asked which elicited more than "yes/no" answers from the respondents. Examples of questions asked in this course include the following: "In what ways do the training and development enterprise impact and become impacted by other HR functional areas? Explain how training and develop are impacted by staffing and compensation strategies. Provide a real-world example." A second question "Training and development are often based on organizational needs. Sometimes trainers forget about the trainees. Based on the material in Chapter 4 and additional readings on the ASTD website concerning child and adult learning theories, what recommendations would you make to your group (its own business) concerning the training you suggested in the last (previous) discussion board? How would you apply learning theories in the program design? Are the characteristics of adult learners true for your group? If so, in what 
ways? If not, how are they different? What additional opportunities and challenges does the existence of four generations in the workplace provide?" Finally, "As the U.S. workforce becomes increasingly diverse, including age, race, gender, national origin, language and religion, there are additional challenges in managing diversity and capitalizing on the unique capabilities that individuals bring to the workplace. Based on Noe's chapters on employee and career development and "special issues" (Chapters 10-12), outline your plan for ensuring that ALL individuals within the workforce are given training and developmental opportunities, while ensuring that your strategies, policies and practices meet organizational effectiveness and financial needs. Using the ADDIE principles, evaluate the training and career development interventions. What information is critical for you to have in order to be able to help you $r$ organization be successful in this endeavor?"

Another attempt was made to build community within the course, beyond the required (then discarded) webpage development. As mentioned previously, "Water Cooler" was utilized, with the following instructions: "This section of Blackboard Discussion Board allows you to begin to introduce yourselves to your classmates. Please share three things that you like to do and three things that you absolutely would pay a million dollars to have someone else to do. Since you know that lots of people will read this information, make sure you share only what you don't mind being put up on the busiest highway in your area. The third opportunity to encourage students to utilize Blackboard was the use of animations throughout the course and the inclusion of "Take A Break" in Blackboard. There were some motivational quotes and time wasters included for students within course documents, as well as helpful hints on how they could create a learning oasis within their own learning environment.

\section{Results}

Although this was a web-based course with only one opportunity for face-to-face interaction, students did not engage with the technology at the level needed for success in the course. See Table 1 for usage of Discussion Board in Blackboard.
Electronic Journal Entries were required for each student for reflection and to note questions they would like to ask the faculty member. In addition, there was a section in Blackboard for students to ask questions about their homework or to report difficulty they were experiencing with the technology. There were a number of technology failures. Blackboard was taken down for maintenance on several occasions when students expected it to be available. Digital dropbox frequently malfunctioned, and students were not able to have confidence that their submitted work would be received by the faculty member. As a result, students used digital dropbox, campus e-mail, and the faculty member's business e-mail to ensure delivery of their work.

Multimedia presentations were required for the three required projects. The technological requirements for these projects included: Access to websites, embedded videos, voiceover, preand post-tests, photo, high-quality graphics, and appropriately formatted powerpoint. A detailed multimedia presentation rubric was provided as well. Electronic presentations, supporting documentation, and instructor manuals were also required for these projects.

\section{CONCLUSION}

Consistent with the IT literature around the technology acceptance model, undergraduate students who were forced to take an on-line class which was offered only once a year, did not embrace or fully use the technology. When required to engage with the technology with projects constituting $2 / 3 \mathrm{~s}$ of their grades, the students who typically did not embrace technology scored $20 \%$ lower than those who had actively engaged with the technology. One student did not take the final exam which was launched through Blackboard. Two students were kicked out of the mid-term exam because of technology glitches and scored significantly lower than other students when allowed to reenter later that evening. The students who had their own computers did better than the students who had to use on-campus resources. Therefore, convenience of technology was also a factor. Finally, students who felt confident about their use of technology created more aesthetically pleasing and technologically sophisticated multimedia projects. 
The challenges with technology, at times, overrode what we were trying to accomplish through the critical thinking activities and exercises. Students may have had the "right" answers or the right processes for the answers. The technology challenges provided a confound, and we cannot say definitively whether the critical thinking presented the challenges for them, or if they failed to engage in critical thinking because of the technology. What is clear, however, is that technologically savvy students (rather, students who utilized the technology) performed more successfully on their activities than did students who did not engage with the technology. Furthermore, students were engaged in asynchronous learning, which limited the level of interaction they had with each other. Students who learn better through small group interaction may have experienced difficulty as there was a misalignment between their disposition, learning styles and mode of instructional delivery. The tests and several graded activities also required passwords to access. The passwords were changed frequently to increase the academic integrity of those graded materials. Interpersonal preferences and lack of attention to passwords and password changes also created a level of frustration for the students. Because their password questions were not answered in real time, they may have experienced de-motivation. The students often responded to discussion board or sent e-mails between midnight and 4:00 a.m., at times the faculty member was typically NOT logged into Blackboard.

Technology has the potential to create an interesting and dynamic learning environment for students. It is critical, however, that the appropriate levels of support be available to assist students with technology malfunctions, comfort with technology use, access to technology, and the loss of the community of real-time face-to-face learners. Finally, it is critical that back-up systems are in place when there are technology glitches, scheduled maintenance during the regular semester, early closings at both university and other public computer facilities, and helpdesk.

\section{FUTURE RESEARCH}

A more robust study with a larger class and use of in-class support to bolster student confidence may be a way of ferreting out what actually had the greater impact on student learning outcomes.

\section{REFERENCES}

1. Au, N., Ngai, E., \& Cheng, T. (2008). Extending the understanding of end user information systems satisfaction formation: An equitable needs fulfillment model approach, MIS Quarterly, 32(1), 43-66.

2. Barnett, R. (2004). Learning for an unknown future. Higher Education Research and Development, 23(3), 247260.

3. Bartlett, J.E. (2002). Analysis of motivational orientation and learning strategies of high school business students. Business Education Forum, 56(4), 18-23.

4. Bloom, B.S. (1956). Taxonomy of Educational Objectives, Handbook 1: The Cognitive Domain. New York: David McKay Co., Inc.

5. Chickering, A.W. and Gamson, Z.F. (1987). Seven principles for good practice in undergraduate education, AAHE Bulletin, p. 3-7.

6. Davis, F. (1989). Perceived usefulness, perceived ease of use, and user acceptance of information technology. MIS Quarterly, 13(3), 319-340.

7. Doherty, N. (2003). The impact of inadequacies in the treatment of organizational issues on information systems development projects. Information \& Management, 41(1), 4962.

8. Ewusi-Mensah, K. (1997). Critical issues in abandoned information systems development projects. Communications of the ACM, 40(9),7480

9. Facione, Peter (1990) Critical thinking: A statement of expert consensus for purposes of educational assessment and instruction. Willbrae: CA: California Academic Press. 
10. Facione, P.A. (2006). How to use the holistic critical thinking rubric. Retrieved http://insightassessment.com/pdf_files/ Rubric\%20HCTSR.pdf30210.

11. Facione, Peter (2007). Critical thinking: What it is and why it counts. Millbrae, CA: California Academic Press.

12. Facione, P.A., Sanchez (Giancarlo) CA, Facione, NC and Gainen, J. (1995). The disposition toward critical thinking. Journal of General Education. Volume 44, Number(1). 1-25.

13. Ferrett, S. (1997). Peak Performance: Success in College and Beyond.

14. Fowler, B. (Retrieved 2009) . "Critical Thinking Across the Curriculum Project, Longview Community College" http://mcckc.edu/longview/ctac/definiti ons.htm 2/2/28, p. 4 .

15. Gallo, D. (1994). "Educating for empathy, reason, and imagination in Re-Thinking Reason, New Perspectives in Critical Thinking, 181-198.

16. Garrison, D.R., Anderson, T. \& Archer W. (2001). Critical thinking, cognitive presence, and computer conferencing in distance education. American Journal of Distance Education, 15(1), 7-23.

17. Garrison, D. R. and Vaughan, N.D. (2008). Blended Learning in Higher Education: Framework, Principles, and Guidelines, Jossey-Bass.

18. Guillemette, R.A. (1991). Domains of educational objectives: An information systems perspective. Journal of College Information Systems, 31(4), 18-25.

19. Halpern, D. F. (1996) Thought and Knowledge: An Introduction to Critical Thinking.

20. Halpern, D.F. (1999). Teaching for critical thinking: Helping college students develop the skills and dispositions of a critical thinker. New
Directions for Teaching and Learning, Vol. 1999, Issue 80, pp. 69-74.

21. Lorenzi, N. (2003). Organizational issues $=$ change. International Journal of Medical Informatics, 69(2-3), 197203.

22. McClure, D. (2007). From the CIO Trenches: Why Some Projects Fail and Others Succeed. Stamford, CT: Gartner Group.

23. Norris, Stephen P. (1985). Synthesis of research on critical thinking. Educational Leadership, v. 42 n 8 May.

24. Oz, E. \& Sosik, J.J. (2000). Why information systems projects are abandoned: a leadership and communication theory and exploratory study. Journal of Computer Information Systems, 41(1), 66-78.

25. Partnership for $21^{\text {st }}$ Century Skills, Conference Board and SHRM (2006). Are they really ready to work? Employers' Perspectives on the Basic Knowledge and Applied Skills

of New Entrants to the 21st

Century U.S. Workforce.

26. Perkins, S. and Tishman, A. (1998). Thinking dispositions: A review of current theories, practices, and issues. http://learnweb.harvard.edu/alps/thinkin g/docs/Dispositions.htm Retrieved 7/24/2010.

27. Perkins, D. N., Jay, E., \& Tishman, S. (1993). Beyond abilities: A dispositional theory of thinking. The Merrill-Palmer Quarterly, 39(1), 1-21.

28. Rippin, A., Booth, C., Bowie, S., \& Jordan, J. (2002). A complex case: Using the case study method to explore uncertainty and ambiguity in undergraduate business education. Teaching in Higher Education, 7(4), 429.

29. Scriven, M. and Paul R. (2008). Defining Critical Thinking" for the National Council for Excellence in Critical Thinking Instruction. 
30. Scriven, M. and Paul, R. (2001) Defining Critical Thinking. Retrieved http://unilearning.uow.edu.au/critical/1a .html3/2/2010.

31. Shakirova, D.M. (2007). Technology for the shaping of college students' and upper-grade students' critical thinking. Russian Education \& Society, 49(9), 4245 .

32. Shibley, A.I. (2009). Putting the learning in blended learning. Online $\mathrm{Cl} @$ ssroom, A Magna Publication.

33. SHRM (2007). SHRM 2007 Symposium on the Workforce Readiness of the Future U.S. Labor Pool: Critical Skills needed for the Changing Workforce. SHRM Foundation.

34. Simon, H. A. and C. A. Kaplan (1989). In MI. Posner (Ed), Foundations of cognitive sciences. Cambridge, MA, MIT Press: 1-47.

35. Tempelaar, D.T. (2006). The role of meta-cognition in business education. Industry and Higher Education, 20(5), 291-297.
36. Walker, P. \& Finney, N. (1999). Skill development and critical thinking in higher education. Teaching in Higher Education.

37. Walters, K.S. (1994) "Beyond logicism in critical thinking," Re-Thinking Reason: New Perspectives in Critical Thinking, Kerry S. Walters, ed. Albany: SUNY Press, 1-22.

38. Wright, L. (1997). Critical Thinking: An Introduction to Analytical Reading and Reasoning, p. 29.

39. Yang, Y.T.C., Newby, T.J. \& Bill, R.L. (2005). Using Socratic questioning to promote critical thinking skills through asynchronous discussion forums in distance learning environments. The American Journal of Distance Education, 19*3), 163-181.

40. Yeh, Y. (2006). The interactive effects of personal traits and guides practice on preservice teachers' changes in personal teaching efficacy. British Journal of Educational Technology, 37(4), 513526. 
Table 1 - Responses to Discussion Board

\begin{tabular}{|c|c|c|c|c|}
\hline Discussion Board \# & $\begin{array}{c}\text { Total } \\
\text { Participants }\end{array}$ & Total Posts & $\begin{array}{c}\text { Average } \\
\text { Responses } \\
\text { Per } \\
\text { Participant }\end{array}$ & Comments, If Needed \\
\hline $\begin{array}{l}\text { Introductory Discussion } \\
\text { Board }\end{array}$ & 5 & 9 & 1.8 & \\
\hline Water Cooler & 7 & 16 & 2.285 & \\
\hline Electronic Journal & 6 & 14 & 2.33 & \\
\hline Take a Break & 0 & 0 & 0 & $\begin{array}{l}\text { Students did not engage with this link at all. } \\
\text { Either the material was not meaningful to them, or } \\
\text { they found non-Blackboard ways of relaxing. }\end{array}$ \\
\hline $\begin{array}{l}\text { Technology/Homework } \\
\text { Clarification }\end{array}$ & 6 & 3 & 2 & \\
\hline Week 1 - Training & 19 & 7 & 2.714 & \\
\hline Week 2 - Strategic Training & 10 & 5 & 2 & \\
\hline Week 2 Forum 2 & 2 & 2 & 1 & \\
\hline $\begin{array}{l}\text { Week } 3 \text { - Needs } \\
\text { Assessment }\end{array}$ & 2 & 2 & 1 & \\
\hline $\begin{array}{l}\text { Week } 4 \text { - Learning Theories } \\
\text { and Program Design }\end{array}$ & 27 & 8 & 3.375 & \\
\hline $\begin{array}{l}\text { Week } 5-\text { Transfer of } \\
\text { Training }\end{array}$ & 16 & 8 & 2 & \\
\hline $\begin{array}{l}\text { Week } 6 \text { - Training } \\
\text { Instructional Development }\end{array}$ & 11 & 5 & 2.2 & \\
\hline $\begin{array}{l}\text { Weeks } 7 \text { and } 8-\text { Special } \\
\text { Issues in Training and } \\
\text { Development }\end{array}$ & 0 & 0 & 0 & $\begin{array}{l}\text { This was the most integrative question that } \\
\text { students had had to date, and their failure to } \\
\text { respond indicated their lack of willingness or } \\
\text { inability to embrace this level of critical thinking. } \\
\text { Additionally, this was at the time of midterms, } \\
\text { and they may not have had the psychic energy to } \\
\text { engage. }\end{array}$ \\
\hline $\begin{array}{l}\text { Week } 8 \text { - Performance } \\
\text { Management }\end{array}$ & 7 & 3 & 2.3333 & $\begin{array}{l}\text { We moved from one major topic in HR to another } \\
\text { one. Some students did not make the transition } \\
\text { with us. }\end{array}$ \\
\hline Discussion Board \# & $\begin{array}{c}\text { Total } \\
\text { Participants }\end{array}$ & Total Posts & $\begin{array}{l}\text { Average } \\
\text { Responses } \\
\text { Per } \\
\text { Participant }\end{array}$ & Comments, If Needed \\
\hline $\begin{array}{l}\text { Week } 9 \text { - Performance } \\
\text { Management and Strategic } \\
\text { Planning }\end{array}$ & 7 & 3 & 2.3333 & \\
\hline $\begin{array}{l}\text { Week } 10 \text { - Performance } \\
\text { Management Approaches }\end{array}$ & 7 & 4 & 1.75 & \\
\hline $\begin{array}{l}\text { Week } 12 \text { - Implementing a } \\
\text { Performance Management } \\
\text { System }\end{array}$ & 14 & 6 & 2.3333 & $\begin{array}{l}\text { This assignment was less theoretical and more } \\
\text { practically oriented. Students responded more to } \\
\text { this one and asked questions to gain clarification. }\end{array}$ \\
\hline $\begin{array}{l}\text { Week } 13 \text { - Mentoring and } \\
\text { Coaching }\end{array}$ & 0 & 0 & 0 & End of semester - total disengagement. \\
\hline
\end{tabular}

